\title{
Equilibrium Moisture Content and Thin Layer Drying Model of Shiitake Mushrooms Using a Vacuum Heat-pump Dryer
}

\author{
Sirithon Supakarn, Somnuk Theerakulpisut* \\ and Apichart Artnaseaw
}

Faculty of Engineering, Khon Kaen University, Khon Kaen 40002, Thailand

*Corresponding author.E-mail: somthe@kku.ac.th

https://doi.org/10.12982/CMUJNS.2018.0001

\begin{abstract}
The objective of this research was to experimentally determine the equilibrium moisture content of Shiitake mushrooms under vacuum conditions by using a vacuum heat-pump dryer. The mushrooms were dried at a pressure of 0.2 bar and temperatures of 50,55 , and $60^{\circ} \mathrm{C}$. A saturated salt solution was used to control the relative humidity within 10-75\%. This study found that vacuum drying tended to increase the equilibrium moisture content of the mushrooms and the relative humidity as the drying temperature decreased. Of the correlations proposed by Oswin, Guggenheim-Anderson-de Boer (GAB), Peleg, modified Oswin, and modified $G A B$, the functional form of Peleg was the best fit $\left(R^{2}\right.$ of 0.99). The moisture content of the mushrooms, as measured during drying, were used with the equilibrium moisture content values obtained from the proposed equations to determine the moisture ratios of the mushrooms at different drying times. Among nine well-known correlations, the functional form of the thin layer model proposed by Midilli best predicted the drying of Shiitake mushrooms under vacuum.
\end{abstract}

Keywords: Equilibrium moisture content, Shiitake mushroom drying, Vacuum drying, Thin layer drying model

\section{INTRODUCTION}

Shiitake is a popular mushroom with a nice smell, good taste, and high nutritional value; it also provides substances to reduce cholesterol. With regular consumption, it may prevent cancer and some viral infections, like the cold (Shukla and Singh, 2007). Fresh and dried mushrooms are edible, and mushrooms are often dried to reduce lose during transportation and preserve them. Sun drying costs little and is popular in tropical areas. However, sun drying takes a long time and it is difficult to control the climate and humidity, so alternatives such as hot-air, microwave-vacuum, fluidized-bed, and heat-pump driers have been developed. Previous studies have analyzed some of these techniques with different mushrooms - for example, hot air drying of oyster mushrooms at different air temperatures $(50,55,60$, and 
$70^{\circ} \mathrm{C}$ ) (Kotwaliwale et al., 2007), microwave-vacuum and convective hot-air drying of button mushrooms (Giri and Prasad, 2007), and the drying kinetics of white button mushroom (Agaricus bisporus) slices in a fluidized bed dryer (Wakchaure et al., 2010).

Drying can add value to agricultural products, with production techniques focused on optimizing product quality and energy consumption. A recently developed technique dries products under a vacuum; this removes water from moist materials at low pressure and offers several advantages - a higher drying rate, a lower drying temperature, an oxygen-deficient processing environment, and a higher quality product (Hee and Chong, 2015). Artnaseaw (2009) invented a vacuum heat-pump dryer to increase water evaporation from products at a lower pressure than normal, with a low drying temperature and high drying rate. Using this dryer to dry Shiitake mushrooms at temperatures of $50-65^{\circ} \mathrm{C}$ under $0.1-0.4$ bar maintained the quality of the mushrooms, especially color (Supakarn et al., 2009).

Equilibrium moisture content is the moisture content at which the dried product is in equilibrium with the environment, i.e., it neither gains nor loses moisture. The equilibrium moisture content, a measure of thermodynamics, is significant to drying agricultural products, indicating the least possible moisture in the dried product at a specified temperature and relative humidity (Shivhare et al., 2004). It depends on the type of product, air temperature, and relative humidity. Argyropoulos et al. (2011) determined the equilibrium moisture content of Shiitake mushrooms at $25^{\circ} \mathrm{C}$ and varying relative humidity; it fit the GAB model. The objective of this study was to investigate the equilibrium moisture content of Shiitake mushrooms and the functional form of thin layer drying using a vacuum heat-pump dryer designed by Artnaseaw (2009).

\section{MATERIALS AND METHODS}

\section{Shiitake mushrooms}

The Shiitake mushrooms [Lentinula edodes (Berk.) Peg.] used in this study were freshly cultivated with cap diameters from 4-6 cm. The stem was cut off before processing. Fresh mushrooms were divided into two groups. The first group was analyzed for initial moisture by drying at $105^{\circ} \mathrm{C}$ for $72 \mathrm{hrs}$. (AOAC, 2002) and the other group was processed under different drying conditions in the vacuum heat-pump dryer.

\section{The vacuum heat-pump dryer}

This study used a vacuum dryer with a heat pump as the heat source. A schematic diagram of the vacuum heat-pump dryer is shown in Figure 1. The drying chamber is separated from the heat pump and the heat is transferred through the hot coil in the drying chamber by a circulation fan. The control panel included a monitor that showed the temperature and relative humidity inside the drying chamber. The heat and vacuum pumps were turned on and the desired temperature was set. After the drying chamber reached the required temperature, the mushroom samples were placed on the trays in the drying chamber and left to dry until the final moisture content was reached.

During the experiments, temperature, relative humidity, and air velocity in the drying chamber were continually recorded. Each experiment was repeated in triplicate for each drying temperature. To maintain the temperature in the drying chamber, the heat pump was 
run continuously. The drying temperature was controlled by a solenoid valve controlling the flow of hot refrigerant to the internal condenser of the heat pump. The solenoid valve opened and closed when the drying temperature measured by a type-K thermocouple reached maximum and minimum preset values. The water in the cooling tank was cooled to $15-17^{\circ} \mathrm{C}$ to cool the vacuum pump. The change of mass of the mushrooms during drying was measured continually using a load cell with an accuracy of $\pm 0.0001 \mathrm{~g}$. The drying temperatures within the drying chamber were monitored by type-K thermocouples calibrated with a water bath (Grant Instruments, Cambridge, UK) with an accuracy of $\pm 0.5^{\circ} \mathrm{C}\left(5-90^{\circ} \mathrm{C}\right)$ and connected to a model CX-23 data logger (Campbell Scientific Inc, UT, USA). A digital pressure meter with an accuracy of $\pm 0.5 \%$ of the full scale was used to measure pressure in the drying chamber. The pressure in the drying chamber was controlled by controlling the flow of atmospheric air into the drying chamber. Humidity in the drying chamber was measured by a digital humidity meter with an accuracy of $\pm 2 \%$ relative humidity $\left(50-65^{\circ} \mathrm{C}\right)$. A hot wire anemometer with an accuracy of $\pm 2 \%$ of the full scale was used to measure the average air velocity in the drying chamber. Working fluid in the heat pump was R-22.

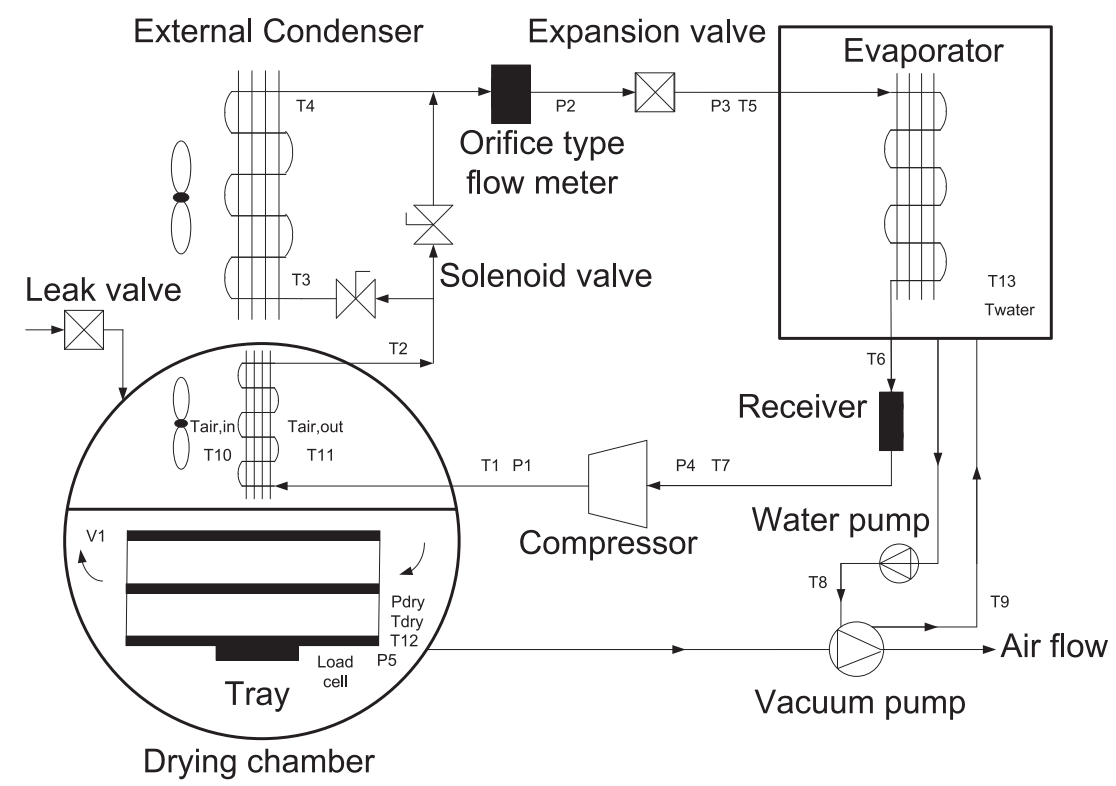

Figure 1. A schematic diagram of the vacuum heat-pump dryer.

\section{Determining the equilibrium moisture content of mushrooms}

To investigate the influence of temperature on the equilibrium moisture content of Shiitake mushrooms, the vacuum heat-pump dryer was set at either 50,55 , or $60^{\circ} \mathrm{C}$, and at a pressure of 0.2 bar with low-pressure air controlled at $1.2 \mathrm{~m} / \mathrm{s}$. The relative humidity of the chamber was varied from 10 to 75 percent using six kinds of saturated salt solutions for each relative humidity range. The compositions of the salt solutions are shown in Table 1. The samples were weighed every five minutes during the experiment until the weight of the specimens was steady. 
Table 1. The amount of salt and distilled water in each prepared saturated salt solution.

\begin{tabular}{lcc}
\hline Salt solution & Salt $(\mathbf{g})$ & Water $(\mathbf{m g})$ \\
\hline $\mathrm{MgCl}_{2}$ & 200 & 25 \\
$\mathrm{~K}_{2} \mathrm{CO}_{3}$ & 200 & 90 \\
$\mathrm{Mg}\left(\mathrm{NO}_{3}\right)_{2}$ & 150 & 30 \\
$\mathrm{KI}$ & 200 & 80 \\
$\mathrm{NaCl}$ & 200 & 60 \\
$\mathrm{KCl}$ & 200 & 80 \\
\hline
\end{tabular}

Source: Wolf et al., 1985.

The saturated salt solutions were each placed in the tray at the floor level of the dryer, and the fresh mushroom samples were placed on the top tray of the dryer for each temperature and relative humidity range. The mushroom samples were dried until their weight was constant. The samples were then removed and transferred to a hot-air oven set $105^{\circ} \mathrm{C}$ for 72 hours to obtain its dried weight. The equilibrium moisture content was then calculated from the original fresh weight and dried weight (AOAC, 2002).

Mathematical models (Table 2) of the relationship between the moisture content of the product and relative humidity of the air can be used to predict the equilibrium moisture content of the final product. Each model has its own pattern, so the most optimal model for the Shiitake mushrooms was selected based on value fitting the results of a correlation comparison. The optimal model for calculating the equilibrium moisture content of the product was then applied.

Table 2. Selected equilibrium moisture content models used in this study.

\begin{tabular}{|c|c|c|}
\hline Model & Equation & References \\
\hline Oswin & $M_{e}=A\left[\frac{R H}{(1-R H)}\right]^{B}$ & Al-Muhtaseb et al. (2004) \\
\hline GAB & $M_{e}=\frac{A B C(R H)}{(1-B(R H))[(1-B(R H))+(B C(R H))]}$ & Ghodake et al. (2007) \\
\hline Peleg & $M_{e}=A(R H)^{B}+C(R H)^{D}$ & Sinija and Mishra (2008) \\
\hline Modified Oswin & $M_{e}=(A+B T)\left[\frac{R H}{(1-R H)}\right]^{\frac{1}{C}}$ & Iguaz and Virseda(2007) \\
\hline Modified GAB & $M_{e}=\frac{(1-B(R H))\left[(1-(R H))+\left(\left(\frac{C}{T}\right) B(R H)\right)\right]}{(1-B)}$ & Oyelade et al. (2008) \\
\hline
\end{tabular}

Note: * $\mathrm{M}_{\mathrm{e}}$, Equilibrium Moisture Content; RH, relative humidity; T, temperature $\left({ }^{\circ} \mathrm{C}\right) ; \mathrm{A}, \mathrm{B}, \mathrm{C}$, and $\mathrm{D}$, dimensionless coefficients specific to the individual equation. 
Data from the experiments were analyzed with each of the five mathematical models of equilibrium moisture content; the coefficient of determination $\left(\mathrm{R}^{2}\right)$ and standard error of estimate (SEE) were used to identify the model that best predicted the equilibrium moisture content values of the Shiitake mushroom samples. SEE can be calculated as:

$$
S E E=\sqrt{\frac{\sum_{i=1}^{N}\left(M_{e(\exp )}-M_{e(\text { pre })}\right)^{2}}{d f}}
$$

where $\mathrm{M}_{\mathrm{e(exp)}}$ is the equilibrium moisture content from the experiment, $\mathrm{M}_{\mathrm{e}(\mathrm{pre})}$ is the equilibrium moisture content calculated from the model, $\mathrm{N}$ is the number of data points, and $\mathrm{df}$ is the degree of freedom of the regression model which equals to N-1.

\section{Determining the moisture ratio for drying Shiitake mushrooms}

Moisture ratio from the experiment can be calculated by:

$$
M R=\frac{M-M_{e}}{M_{o}-M_{e}}
$$

where MR is the moisture ratio (no unit), $\mathrm{M}$ is the moisture of the material at a specified time ( $\% \mathrm{db})$, $\mathrm{M}_{0}$ is the initial moisture $(\% \mathrm{db})$, and $\mathrm{M}_{\mathrm{e}}$ is the equilibrium moisture content $(\% \mathrm{db})$.

Table 3. Thin layer drying models used in this study.

\begin{tabular}{lll}
\hline Model & \multicolumn{1}{c}{ Equation } & \multicolumn{1}{c}{ Reference } \\
\hline Newton & $\mathrm{MR}=\exp (-\mathrm{kt})$ & (O'Callaghan et al., 1971) \\
Modified Page & $\mathrm{MR}=\exp (-\mathrm{kt})^{\mathrm{n}}$ & (White et al., 1981) \\
Approximation of diffusion & $\mathrm{MR}=\mathrm{a} \exp (-\mathrm{kt})+(1-\mathrm{a}) \exp (-\mathrm{k} \mathrm{b} \mathrm{t})$ & (Yaldiz et al., 2001) \\
Wang and Singh & $\mathrm{MR}=1+\mathrm{at}+\mathrm{bt}^{2}$ & (Wang and Singh, 1978) \\
ogarithmic & $\mathrm{MR}=\mathrm{a} \exp (-\mathrm{kt})+\mathrm{c}$ & (Togrul and Pehlivan, 2002) \\
Simplified Fick's diffusion & $\mathrm{MR}=\mathrm{a} \exp \left(-\mathrm{c}\left(\mathrm{t} / \mathrm{L}^{2}\right)\right)$ & (Diamante and Munro, 1991) \\
Modified Page equation-II & $\mathrm{MR}=\exp \left(-\mathrm{c}\left(\mathrm{t} / \mathrm{L}^{2}\right)^{\mathrm{n}}\right)$ & (Diamante and Munro, 1991) \\
Two-term model & $\mathrm{MR}=\mathrm{a} \exp \left(-\mathrm{k}_{0} \mathrm{t}\right)+\mathrm{b} \exp \left(-\mathrm{k}_{\mathrm{l}} \mathrm{t}\right)$ & (Henderson, 1974) \\
Midilli & $\mathrm{MR}=\mathrm{a} \exp \left(-\mathrm{kt}^{\mathrm{n}}\right)+\mathrm{bt}$ & (Midilli et al., 2002) \\
\hline
\end{tabular}

To find the statistical correlation between the experimental and model results, nine thin layer models (Table 3) were used to analyze the correlation coefficient $\left(\mathrm{R}^{2}\right)$, reduced chi-square $\left(\mathrm{x}^{2}\right)$, and root mean square error (RMSE) of each experiment condition. Reduced chi-square $\left(\mathrm{x}^{2}\right)$ was calculated by:

$$
x^{2}=\frac{\sum_{i=1}^{N}\left(M R_{\exp }-M R_{p r e}\right)^{2}}{N-z}
$$


RMSE was be calculated by:

$$
R M S E=\sqrt{\frac{1}{N} \sum_{i=1}^{N}\left(M R_{\text {exp }}-M R_{p r e}\right)^{2}}
$$

where, $\mathrm{MR}_{\exp }$ is the moisture ratio from the experiment, $\mathrm{MR}_{\mathrm{pre}}$ is the moisture ratio predicted from the model, $\mathrm{N}$ is the number of values recorded from the experiment, and $\mathrm{Z}$ is the number of constants in the equation.

\section{RESULTS}

\section{Experimental equilibrium moisture content of Shiitake mushrooms}

The relationship between the equilibrium moisture content and relative humidity of the Shiitake mushroom samples at 50,55 and $60^{\circ} \mathrm{C}$ are shown in Figure 2. The lower the drying temperature, the higher the relative humidity, resulting in a higher equilibrium moisture content.

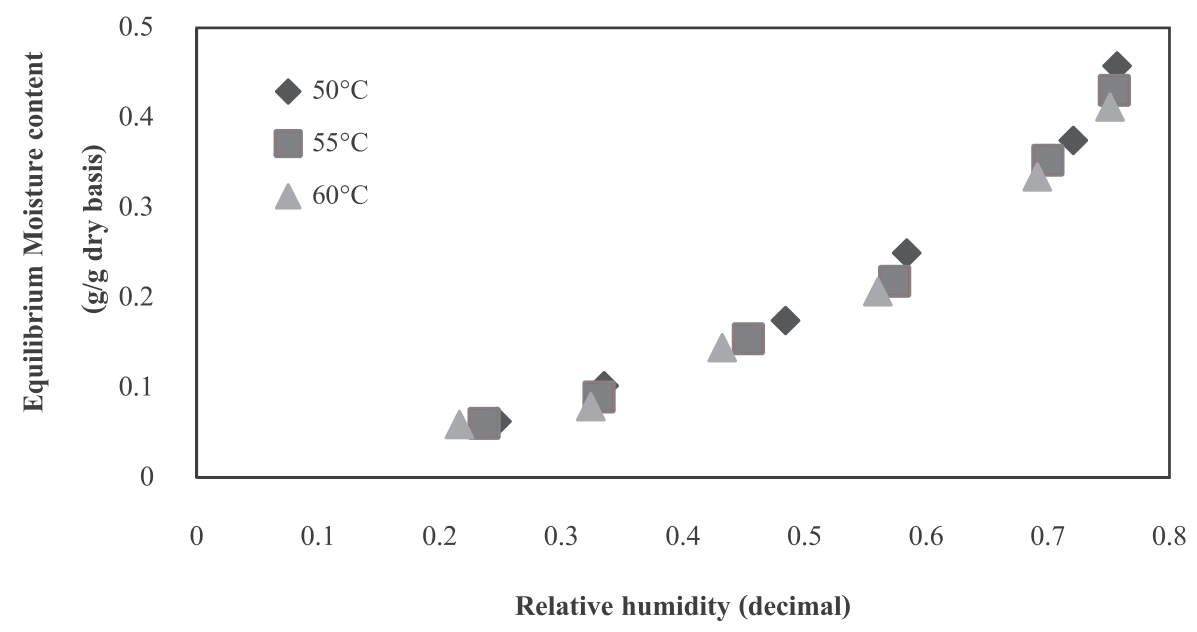

Figure 2. Equilibrium moisture content at different temperatures.

\section{Equilibrium moisture content of Shiitake mushrooms predicted from selected models}

The experimental equilibrium moisture content at each relative humidity were input into each of the five equilibrium moisture content models (Table 1) to obtain the constants (A, $\mathrm{B}, \mathrm{C}$, and D). The constants and relative humidity were then used to calculate the equilibrium moisture content for each model. The correlation $\left(\mathrm{R}^{2}\right)$ between the experimental and predicted equilibrium moisture content, and the SEE were then calculated. Generally, the statistical correlations $\left(\mathrm{R}^{2}\right)$ were highest in Peleg's model and the values of SEE were the lowest among all models. The highest $\mathrm{R}^{2}$ values from Peleg's model were obtained at $50^{\circ} \mathrm{C}$ (Table 4 ). The constants and statistical correlations acquired from Peleg's model at each drying temperature are presented in Table 5 . 
Table 4. Constants and statistical correlations acquired from each equilibrium moisture content model at $50^{\circ} \mathrm{C}$ and pressure of 0.2 bar.

\begin{tabular}{|c|c|c|c|c|c|c|}
\hline \multirow{2}{*}{ Equation } & \multicolumn{4}{|c|}{ Constants } & \multirow{2}{*}{$\mathbf{R}^{2}$} & \multirow{2}{*}{ SEE } \\
\hline & $\mathbf{A}$ & B & $\mathrm{C}$ & D & & \\
\hline Oswin & 0.169474 & 0.817596 & & & 0.9960 & 0.009026 \\
\hline GAB & 2.0759 & 0.690019 & 0.248760 & & 0.9969 & 0.007992 \\
\hline Peleg & 0.286695 & 1.097224 & 0.671208 & 4.182597 & 0.9972 & 0.007544 \\
\hline Modified Oswin & -1183668 & 19728.0 & 1 & & 0.9960 & 0.009026 \\
\hline Modified GAB & 0.806830 & 0.269990 & 50.4434 & & 0.9971 & 0.007780 \\
\hline
\end{tabular}

Table 5. Constants and statistical correlation acquired from Peleg's functional pattern at the conditions of the study of equilibrium moisture content of Shiitake mushrooms.

\begin{tabular}{cccccccc}
\hline \multirow{2}{*}{$\begin{array}{c}\text { Drying } \\
\text { temperature }\end{array}$} & \multicolumn{5}{c}{ Constants acquired from the equation } & \multirow{2}{*}{$\mathbf{R}^{2}$} & \multirow{2}{*}{ SEE } \\
\cline { 2 - 5 } & $\mathbf{A}$ & $\mathbf{B}$ & $\mathbf{C}$ & \multicolumn{1}{c}{$\mathbf{D}$} & & \\
\hline $50^{\circ} \mathrm{C}$ & 33.06397 & 21.51201 & 0.58795 & 1.61960 & 0.9995 & 0.00358 \\
$55^{\circ} \mathrm{C}$ & 0.809824 & 5.939582 & 0.407037 & 1.346054 & 0.9992 & 0.00411 \\
$60^{\circ} \mathrm{C}$ & 0.286695 & 1.097224 & 0.671208 & 4.182597 & 0.9972 & 0.007544 \\
\hline
\end{tabular}

\section{Drying characteristics of Shiitake mushrooms}

When the drying temperature increased, the drying time tended to decrease (Figure 3).

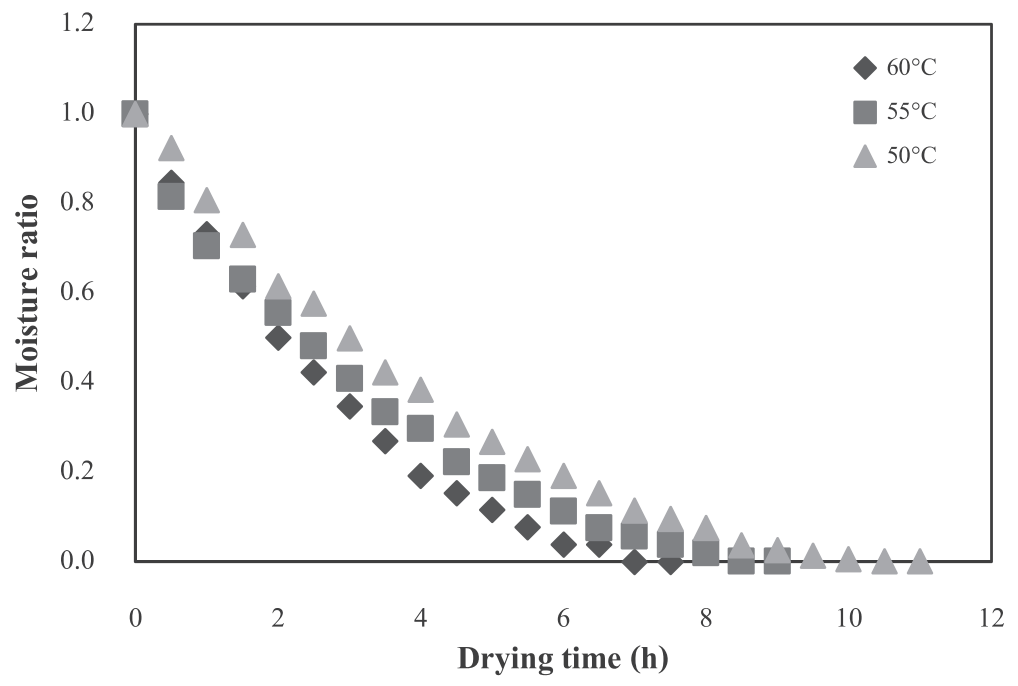

Figure 3. The moisture ratio and drying time for Shiitake mushrooms at different drying temperatures. 


\section{Thin layer drying models of Shiitake mushrooms}

The experimental results were subjected to nonlinear regression analysis to develop the correlations in nine different functional patterns at each experimental condition; these were applied to predict the moisture ratio (MR). Table 6 provides an example, using the experimental results at the drying temperature of $50^{\circ} \mathrm{C}$ and drying pressure of $0.2 \mathrm{bar}$. Among these correlations, the functional form proposed by the Midilli model best predicted the drying of shiitake mushrooms under vacuum conditions (Table 7).

Table 6. Constants and statistical correlation acquired from thin layer drying models at the drying temperature of $50^{\circ} \mathrm{C}$ and drying pressure of 0.2 bar.

\begin{tabular}{|c|c|c|c|c|c|c|c|c|c|}
\hline \multirow{2}{*}{ Functional pattern } & \multicolumn{6}{|c|}{ Constants acquired from the function } & \multirow{2}{*}{$\mathbf{R}^{2}$} & \multirow{2}{*}{$\mathrm{X}^{2}$} & \multirow{2}{*}{ RMSE } \\
\hline & $\mathbf{k}$ & $\mathbf{n}$ & a & $\mathbf{b}$ & c & $\mathbf{L}$ & & & \\
\hline Newton & 0.26797 & & & & & & 0.9913 & 0.0021 & 0.04481 \\
\hline Modified Page & 0.16504 & 1.62367 & & & & & 0.9913 & 0.0022 & 0.04481 \\
\hline $\begin{array}{l}\text { Approximation of } \\
\text { diffusion }\end{array}$ & 0.37472 & & 1.80936 & & & & 0.9955 & 0.0005 & 0.02250 \\
\hline Wang and Singh & & & -0.19275 & 0.00936 & & & 0.9985 & 0.0001 & 0.01214 \\
\hline Logarithmic & 0.20403 & & 1.17579 & & -0.15149 & & 0.9981 & 0.0002 & 0.01350 \\
\hline $\begin{array}{l}\text { Simplified Fick's } \\
\text { diffusion }\end{array}$ & & & 1.06949 & & 0.00380 & 0.11541 & 0.9874 & 0.0017 & 0.03871 \\
\hline $\begin{array}{l}\text { Modified Page } \\
\text { equation-II }\end{array}$ & & 1.27677 & & & 0.00142 & 0.15136 & 0.9962 & 0.0004 & 0.02009 \\
\hline Two-term model & $\begin{array}{l}\mathrm{k}_{0}=0.2856, \\
\mathrm{k}_{1}=0.2856\end{array}$ & & 0.53239 & 0.53709 & & & 0.9874 & 0.0018 & 0.003871 \\
\hline Midilli & 0.18986 & 1.15434 & 0.99825 & -0.00599 & & & 0.9988 & 0.0001 & 0.01077 \\
\hline
\end{tabular}

Table 7. Constants and statistical correlation acquired from Midilli at different drying conditions.

\begin{tabular}{|c|c|c|c|c|c|c|c|}
\hline \multirow{2}{*}{$\begin{array}{c}\text { Drying } \\
\text { temperature }\end{array}$} & \multicolumn{4}{|c|}{ Constants acquired from the equation } & \multirow{2}{*}{$\mathbf{R}^{2}$} & \multirow{2}{*}{$\mathbf{X}^{2}$} & \multirow{2}{*}{ RMSE } \\
\hline & $\mathbf{k}$ & $\mathbf{n}$ & a & $\mathbf{b}$ & & & \\
\hline $50^{\circ} \mathrm{C}$ & 0.189865 & 1.154346 & 0.998251 & -0.00599 & 0.99880 & 0.00014 & 0.01077 \\
\hline $55^{\circ} \mathrm{C}$ & 0.288261 & 0.949823 & 0.984348 & -0.01308 & 0.99760 & 0.00026 & 0.01439 \\
\hline $60^{\circ} \mathrm{C}$ & 0.292120 & 1.130104 & 0.991353 & -0.00934 & 0.99910 & 0.00013 & 0.00968 \\
\hline
\end{tabular}

\section{DISCUSSION}

This study reports the equilibrium moisture content and the thin layer drying characteristics of Shiitake mushrooms under vacuum conditions. Our results showed that a lower drying temperature resulted in a higher relative humidity in the chamber, leading to higher equilibrium moisture content of the mushrooms. At a lower drying temperature, the mushroom samples transferred less heat and mass than at a higher temperature, resulting in higher equilibrium moisture content. Our results corresponded with studies of equilibrium 
moisture content of Khon Khao mushrooms (Poomsa-ad and Wiset, 2007), moisture adsorption isotherms of Inonotus obliquus mushrooms (Lee and Lee, 2008), and the equilibrium moisture content of baby jackfruit (Mani et al., 2014). This study showed that the equilibrium moisture content of Shiitake mushroom can be appropriately predicted by Peleg model; this corresponded to other studies of high-moisture-content materials, including sheet rubber (Jeentada et al., 2012) and bananas (Kluai Nam Wa) (Jeentada and Phetsongkram, 2013). The equilibrium moisture content values obtained from our experimental results were close to those predicted from Peleg's model with SEE of 0.00358, 0.00411, and 0.00754 at 50, 55 and $60^{\circ} \mathrm{C}$, respectively. These SEE values fell within the range reported by Nourhène et al. (2008) and Phoungchandang and Kongpim (2012). The higher drying temperature increased errors due to the greater variation in the relative humidity in the chambers.

The higher the drying temperature, the higher force generated to transfer heat and mass (water vapor). Therefore, drying rates increased with increasing temperature. Initially, the moisture content of the mushroom samples decreased rapidly when drying, because of their naturally high moisture content and the ease of heat and mass transfer at their surface. As drying continued, the drying rates gradually decreased; as the heat was transferred to the interior of the samples, the movement of water vapor to the surface and surrounding air became more retarded. The drying behavior of the Shiitake mushrooms in this study was similar to that reported in pumpkins dried under vacuum conditions (Aroldo and Fernando, 2007) and fenugreek, leek, mint, and parsley dried in a vacuum dryer (Zakipour and Hamidi, 2011). Similar results were also found in Hempedu bumi (Andrographis paniculata, AP) at temperatures between 40 and $60^{\circ} \mathrm{C}$ under vacuum pressures of 10 and $30 \mathrm{kPa}$, in which the two-term drying model was the most suitable for predicting the drying behavior of the leaves and stem of $A$. paniculata (Hee and Chong, 2015). In our study, the drying of Shiitake mushrooms also fit the 'two-term' model, but with a slightly lower $\mathrm{R}^{2}$ and higher RMSE than those of Midilli et al. (2002).

Our preliminary experiment at pressure 0.2 bar showed that drying at temperatures lower than $50^{\circ} \mathrm{C}$ resulted in spoilage of the Shiitake mushrooms by microorganisms. Alternatively, drying temperatures higher than $60^{\circ} \mathrm{C}$ overheated the compressor, damaging the equipment and ending the experiment. While lower pressures than we used produced greater drying rates, they were difficult to control experimentally, so we fixed the air pressure at 0.2 bar and the hot air velocity at $1.2 \mathrm{~m} / \mathrm{s}$ due to limitations of the equipment.

\section{CONCLUSION}

Our study determined the equilibrium moisture content of Shiitake mushrooms dried under vacuum conditions ( 0.2 bar) using a vacuum heat-pump dryer at either 50,55 , or $60^{\circ} \mathrm{C}$ and under relative humidity varied from 10 to 75 percent. The temperature, pressure, and relative humidity affected the equilibrium moisture content of the mushroom samples. When the drying temperature decreased, the equilibrium moisture content increased. A higher drying temperature led to a higher drying ratio and shorter drying time. We also found that Peleg's model best predicted the equilibrium moisture content of Shiitake mushrooms. In addition, the thin-layer drying model of Midilli best explained the drying behavior of the Shiitake mushrooms. 


\section{ACKNOWLEDGEMENTS}

The authors would like to express their gratitude to the Energy Management and Conservation Office (EMCO) of Khon Kaen University for its financial support of the project and the Department of Mechanical Engineering, Faculty of Engineering, Khon Kaen University for generously providing the facilities.

\section{REFERENCES}

Al-Muhtaseb, A.H., McMinn, W.A.M., and Magee, T.R.A. 2004. Water sorption isotherms of starch powders Part 1, mathematical description of experimental data. Journal of Food Engineering. 61(3): 297-307. https://doi.org/10.1016/S0260-8774(03)00133-X

Argyropoulos, D., Alexb, R., and Müller, J. 2011. Equilibrium moisture contents of a medicinal herb (Melissa officinalis) and a medicinal mushroom (Lentinula edodes) determined by dynamic vapor sorption. Procedia Food Science. 1: 165-172. https://doi.org/10.1016/j. profoo.2011.09.026

Aroldo, A.P., and Fernando, E.X.M. 2007. Influence of pre-treatments on the drying kinetics during vacuum drying of carrot and pumpkin. Journal of Food Engineering. 80(1): 152156. https://doi.org/10.1016/j.jfoodeng.2006.05.005

Artnaseaw, A. 2009. Vacuum heat pump drying of herbs [PhD thesis]. Khon Kaen: Khon Kaen University; Thai.

AOAC. 2002. Official methods of the association of official analytical chemists. Association of Official Analytical Chemists, Washington D.C.

Diamante, L.M., and Munro, P.A. 1991. Mathematical modeling of hot air drying of sweet potato slices. International Journal of Food Science and Technology. 26(1): 99-109. https://doi.org/10.1111/j.1365-2621.1991.tb01145.x

Ghodake, H.M., Goswami, T.K., and Chakraverty, A. 2007. Moisture sorption isotherms, heat of sorption and vaporization of withered leaves, black and green tea. Journal of Food Engineering. 78(3): 827-835. https://doi.org/10.1016/j.jfoodeng.2005.11.023

Giri, S.K., and Prasad, S. 2007. Drying kinetics and rehydration characteristics of microwavevacuum and convective hot-air dried mushrooms. Journal of Food Engineering. 78: 512-521. https://doi.org/10.1016/j.foodeng. 2005.10.021

Hee, Y.Y., and Chong, G.H. 2015. Drying behaviour of Andrographis paniculata in vacuum drying. International Food Research Journal. 22(1): 393-397.

Henderson, S.M. 1974. Progress in developing the thin layer drying equation. Transactions of ASAC. 17(6): 1167-1172. https://doi.org/10.13031/2013.37052

Iguaz, A., and Virseda, P. 2007. Moisture desorption isotherms of rough rice at high temperatures. Journal of Food Engineering. 79(3): 794-802. https://doi.org/10.1016/j. jfoodeng.2006.03.002

Jeentada, W., Chankrachang, T., Chooklin, S., and Sirirak, C. 2012. Comparison of mathematical models equilibrium moisture content for sheet rubber. KKU Engineering Journal. 39(1): 11-21.

Jeentada, W., and Phetsongkram P. 2013. Equilibrium moisture content model for banana (Kluai Nam Wa). KKU Engineering Journal. 40(2): 193-202. 
Kotwaliwale N., Bakane P., and Verma A. 2007. Changes in textural and optical properties of oyster mushroom during hot air drying. Journal of Food Engineering. 78(4): 12071211. https://doi.org/10.1016/j.jfoodeng.2005.12.033

Lee, J.H., and Lee, M.J. 2008. Effect of drying method on the moisture sorption isotherms for Inonotus obliquus mushroom. Food Science and Technology. 41(8): 1478-1484. https://doi.org/10.1016/j.1wt.2007.08.016

Mani, M., Chunyong, N., Khongrattana, P., and Choosiri, N. 2014. Equilibrium moisture content of baby jackfruit. Thaksin University Journal. 17(3): 230-238.

Midilli, A., Kucuk, H., and Yapar, Z. 2002. A New model for single layer drying. Drying Technology. 20(7): 1503-1513. https://doi.org/10.1081/DRT-120005864

Nourhène, B., Neila, B., Mohammed, K., and Nabil, K. 2008. Sorptions isotherms and isosteric heats of sorption of olive leaves (Chemlali variety): Experimental and mathematical investigations. Food and Bioproducts Processing. 86(3): 167-175. https:// doi.org/10.1016/j.fbp.2007.10.010

Oyelade, O.J., Tunde-Akintunde, T.Y., Igbeka, J.C., Oke, M.O., and Raji, O.Y. 2008. Modelling moisture sorption isotherms for maize flour. Journal of Stored Products Research. 44(2): 179-185. https://doi.org/10.1016/j.jspr.2007.10.005

O’Callaghan, J.R., Menzies, D.J., and Bailey, H.D. 1971. Digital simulation of agricultural dryer performance. Journal of Agricultural Engineering Research. 16(3): 223-244. https://doi.org/10.1016/S0021-8634(71)80016-1

Phoungchandang, S., and Kongpim, P. 2012. Modeling using a new thin-layer drying model and drying charactistic of sweet basil (Ocimum baslicum linn.) using tray and heat pump-assisted dehumidified drying. Journal of Process Engineering. 35(6): 851-862. https://doi.org/10.1111/j.1745-4530.2010.00633.X

Poomsa-ad, N., and Wiset, L. 2007. Thin layer drying equation and equilibrium moisture content of Khon Khao mushroom. Agricultural Science Journal. 38(5): 361-364.

Shivhare, U.S., Arora, S., Ahmed, J., and Raghavan, G.S.V. 2004. Moisture adsorption isotherms for mushroom. LWT-Food Science and Technology. 37(1): 133-137. https:// doi.org/10.1016/S0023-6438(03)00135-X

Shukla, B.D., and Singh, S.P. 2007. Osmo-convective drying of cauliflower, mushroom and greenpea. Journal of Food Engineering. 80(2): 741-747. https://doi.org/10.1016/j. jfoodeng.2006.06.025

Sinija, V.R., and Mishra, H.N. 2008. Moisture sorption isotherms and heat of sorption of instant (soluble) green tea powder and green tea granules. Journal of Food Engineering. 86(4): 494-500. https://doi.org/10.1016/j.jfoodeng..2007.10.026

Supakarn, S., Theerakulpisut, S., and Artnaseaw, A. 2010. Drying by using heat pump vacuum dryer. Proceeding of the $1^{\text {st }}$ National Energy Congress: Energy Crisis and Solutions for Thailand on 18-19 February 2010. 162-167. Bangkok: The Engineering Institute of Thailand under H.M. The King's Patronage.

Togrul, I.T., and Pehlivan, D. 2002. Mathematical modeling of solar Drying of apricots in thin layers. Journal of Food Engineering. 55(3): 209-216. https://doi.org/10.1016/S02608774(02)00065-1

Wang, C.Y., and Singh, R.P. 1978. Use of variable equilibrium moisture content in modeling rice drying. Transactions of American Society of Agricultural Engineers. 11: 668-672. 
White, G.M., Ross, I.J., and Ponelert, R. 1981. Fully exposed drying of popcorn. Transactions of the ASAE. 24(2): 466-468. https://doi.org/10.13031/2013.34276

Wolf, A., Swift, J.B., Swinney, H.L., and Vastano, J.A. 1985. Determining lyapunov exponents from a time series. Amsterdam: North-Holland Physics Publishing Division.

Wakchaure, G.C., Manikandan, K., Mani, I., and Shirur, M. 2010. Kinetics of thin layer drying of button mushroom. Journal of Agricultural Engineering. 47(4): 41-46.

Yaldiz, O., Ertekin, C., and Uzun, H.I. 2001. Mathematical modeling of thin layer solar drying of sultana grapes. Energy. 26(5): 457-465. https://doi.org/10.1016/S03605442(01)00018-4

Zakipour, E., and Hamidi, Z. 2011. Vacuum drying characteristics of some vegetables. Iranian Journal of Chemistry and Chemical Engineering. 30(4): 97-105. 